\title{
The Impact of Microfinance on Entrepreneurship in Kyrgyzstan
}

\author{
Asst. Prof. Dr. Kamalbek Karymshakov (Kyrgyzstan-Turkey Manas University, Kyrgyzstan) \\ $\mathrm{Ph}$. D. Candidate Kadyrbek Sultakeev (Kyrgyzstan-Turkey Manas University, Kyrgyzstan) \\ $\mathrm{Ph}$. D. Candidate Burulcha Sulaimanova (Kyrgyzstan-Turkey Manas University, Kyrgyzstan)
}

\begin{abstract}
This paper aims to investigate the impact of microfinance on entrepreneurship in Kyrgyzstan. For estimation the nationally representative "Kyrgyz Integrated Household Survey" for 2013 is used, which covers around 5000 households from all regions in the country. The main variable of interest, the probability of being an entrepreneur of household members depends on individual, household level characteristics and on microfinance loan receiving status. Following the literature, due to the endogeneity issue in using microcredit loan in estimation, this research applies binary response model with instrumental variables. Estimation results show that participation in the micro loan raises the probability of individual to be entrepreneur.
\end{abstract}

\section{Introduction}

Lack of access to crediting in low-income countries is generally seen as one of the main impediments in developing entrepreneurial activities. Individuals with low income or limited wealth have no access to loans from the banking system, due to absence of collateral, while microfinance institutions (MFI) are solving this issue, enabling financial access to all. The importance of microfinance organizations, in facilitating the financial resources to borrowers, has risen rapidly in the last ten years in Kyrgyzstan. In spite of the fact that the financial services of microfinance institutions including microcredit, insurance, savings, money transfers and other financial products are targeted to support poor and low-income borrowers; in the case of Kyrgyz Republic it works mainly in giving microcredit only. In 2002 Kyrgyz Republic has adopted a law "On microfinance organizations", under which MFIs can determine their own sizes of loans and interest rates, as well as commission rates. This, in turn, enabled rapid start-ups in this sector, reaching MFIs loan portfolio share with respect to GDP of country up to 8\%. Thus, since 2002 the number of MFIs increased from 18 to 204, while the loan amount has grown more than 16 times (from $\$ 1$ billion KGS to 16.8 billion KGS) and number of borrowers increased from 80000 to 429000 people.

According to the National Bank of the Kyrgyz Republic, in 2014 the microfinance sector is represented by 5 microfinance companies, 145 microcredit companies and 54 microcredit agencies. Such statistics show widespread characteristics of MFIs in Kyrgyzstan, where total population is around 5.5 million people. Moreover, according to National Statistical Committee of Kyrgyz Republic (NSCKR) in 2014 the $72 \%$ percent of borrowers of MFIs are between 30 and 60 ages, while $20 \%$ are people younger than 30 years; this shows that the most of microfinance clients are in working age and can use credits in income generating activities. It is important to mention that, according to NSCKR, the share of women borrowers in all regions of Kyrgyzstan is bigger. In 2014 the $64 \%$ of borrowers were women, while only $36 \%$ were men. Another significant fact is that $65 \%$ of total population lives in rural areas and microcredit loans are widely used for agricultural purposes, which includes credits for cultivating crops and processing agricultural products by small firms or self-employed workers. Another purpose of microcredit loan is to use it in trading and catering, which are mainly presented by small enterprises or own-account workers in Kyrgyzstan. In average, the amount of loans value around 66,400 KGS (1 050 USD), shows that microfinance institutions are commonly facilitating credits to the poorer people in the country, which is $35 \%$ of total population (NSCKR).

Empirical evidence on the microfinance impact on the enterprises in general show that participation in microcredit program have positive effects, thus microcredit loan relaxes credit constraints, which in turn enables entrepreneurs to manage financial resources optimally and to increase the business revenue, profits and employment (see Karlan and Valdiva (2011); Field et al. (2013); Buera et al. (2012); Kholis (2009); Babajide (2012); Wang (2013)). However, few studies have been undertaken in investigating how microfinance influences entrepreneurial decision of beneficiaries'. One of recent studies on this belongs to Amin et al. (2012) who assessed the impact of microcredit loan on women entrepreneurship in Bangladesh. He found that the access to microcredit has a significant positive impact both on women and men entrepreneurs. Limited studies have been undertaken to analyze the microfinance impact in Kyrgyzstan case, and they mostly consist of qualitative evaluation and analysis of microfinance institutions in Kyrgyzstan. To our best knowledge there are only two empirical studies on microfinance impact in Kyrgyzstan case. Sultakeev (2012) investigates the effect of microcredit on microenterprises income in Kyrgyzstan. Angioloni et al. (2013), which empirically assesses the impact of microcredit loan on household welfare. However, the study of Sultakeev (2012), suffers from some limitations, such that sample size of the study is small and covers only two regions out of seven region of the country and not nationally representative. While the research of Angioloni et al. (2013) which estimates welfare effect of microfinance impact, do not correct the endogeneity issue, which is arising from microcredit program 
participation. For the given reasons and due to the importance of microfinance in facilitating access on financial resources among all regions of Kyrgyzstan and its availability to the low-income borrowers, this paper aims to empirically investigate how micro-credit impact the entrepreneurial decision of beneficiers in Kyrgyzstan.

The paper is organized as follows: in section two, the information of data used and its descriptive statistics are given; in third section the methodology with variable description are presented; in fourth and fifth sections empirical estimation results and conclusion are provided.

\section{Data and descriptive statistics}

To investigate the microfinance impact on entrepreneurship in Kyrgyzstan the Kyrgyz Integrated Household Survey (KIHS) data for 2013 is used. This survey was conducted by National Statistics Committee of Kyrgyzstan, and includes sample of 5000 households and representative at the national level, as well as for urban and rural areas of the country. Also, this survey includes wide range of data information on household characteristics (composition, education, child education, health etc.) and individual (education, health, labor market participation, movements etc.) characteristics.

The table 1 describes the main individual and household characteristics, such as age, gender, marital status, education level of individual, residential and compositional specification of the households, both for borrowers and non-borrowers from microfinance institutions. In general, there is no significant difference in ages between borrowers and non-borrowers, and most of the borrowers are married.

\begin{tabular}{|c|c|c|c|c|c|}
\hline & \multirow[t]{2}{*}{ Total } & \multicolumn{2}{|c|}{$\begin{array}{l}\text { Microcredit non- } \\
\text { borrowers }\end{array}$} & \multicolumn{2}{|c|}{ Microcredit borrowers } \\
\hline & & Amount & $\%$ & Amount & $\%$ \\
\hline \multicolumn{6}{|l|}{ Individual characteristics: } \\
\hline Age & 40.0634 & 40.04683 & - & 40.56458 & - \\
\hline \multicolumn{6}{|l|}{ Marital status } \\
\hline - $\quad$ Married & 11971 & 11597 & 75.22 & 374 & 77.92 \\
\hline - $\quad$ Single, divorced, widowed & 3926 & 3820 & 24.74 & 106 & 22.08 \\
\hline \multicolumn{6}{|l|}{ Occupational choice: } \\
\hline - $\quad$ Entrepreneurs & 3592 & 3438 & 22.30 & 154 & 32.08 \\
\hline - $\quad$ Employee & 9890 & 9592 & 62.22 & 298 & 62.08 \\
\hline - $\quad$ Family contributing worker & 2415 & 2387 & 15.48 & 28 & 5.83 \\
\hline \multicolumn{6}{|l|}{ Education level: } \\
\hline - $\quad$ Secondary, basic & 9132 & 8849 & 57.4 & 283 & 58.96 \\
\hline - $\quad$ Technical education & 2203 & 2155 & 13.98 & 48 & 10.00 \\
\hline $\begin{array}{ll}- & \text { Tertiary education } \\
\end{array}$ & 4563 & 4413 & 28.62 & 149 & 31.04 \\
\hline \multicolumn{6}{|l|}{ Household characteristics: } \\
\hline - Household size (mean) & 4.5199 & 4.5137 & - & 4.7208 & - \\
\hline - Child ratio, $0-5$ years & 0.1193 & 0.1192 & - & 0.1252 & - \\
\hline - Child ratio, 6-17 years & 0.2094 & 0.2091 & - & 0.2218 & - \\
\hline \multicolumn{6}{|l|}{ Residence } \\
\hline - Urban & 7118 & 6967 & 45.19 & 150 & 31.25 \\
\hline - Rural & 8780 & 8450 & 54.81 & 330 & 68.75 \\
\hline $\begin{array}{l}\text { Household total expenditure per } \\
\text { capita (mean, in soms) }\end{array}$ & 36067.72 & 35800.62 & - & 44646.41 & - \\
\hline $\begin{array}{l}\text { Household micro-credit loan } \\
\text { (mean, in soms) }\end{array}$ & - & - & - & 18135.63 & - \\
\hline
\end{tabular}

Table 1. Basic characteristics of microcredit borrowers and non-borrowers; Source: KIHS data, 2013

The occupational choice distribution of micro-credit borrowers shows that significant parts of borrowers are employees, almost $63 \%$. However, the share of entrepreneurs borrowing microcredits is high as well, reaching $33 \%$ of total micro-credit borrowers, showing that these loans may be used in facilitating income generating activities, which are related with works, such as enlarging business, employing more workers, increasing production etc.

More than half of individuals borrowing micro-credit have secondary and basic education, while $31.04 \%$ have tertiary education. The share of borrowers with technical education, is much more less, and counts around 10 percent.

Around $70 \%$ of borrowers are residing in rural areas, showing that the micro-credits are mostly demanded by rural population rather than urban. This could be explained with high concentration of banks and financial 
institutions in urban areas, which are enabling customers to choose credits among various types of organizations. While in rural areas it is mostly the micro finance institutions, which have micro loan to population.

Expenditure per capita in borrower-households is in average more for 8000 soms than in non-borrower households. The household size and its composition do not differ significantly among borrower and nonborrower households.

\section{Methodology}

The probability of individual to be an entrepreneur $\left(y_{1 i}\right)$ will be estimated with binary choice model, Probit model; which will be conditional on receiving micro credit loan $\left(y_{2 i}\right)$, individual, household characteristics $\left(x_{1 i}\right)$. Formally, model is given below (Newey, 1987):

$$
\begin{aligned}
& y_{1 i}=z_{i} \delta+u_{i} \\
& y_{2 i}=x_{i} \Pi+v_{i}
\end{aligned}
$$

where $z_{i}=\left(y_{2 i}, x_{1 i}\right), x_{i}=\left(x_{1 i}, x_{2 i}\right), \delta$ and $\Pi$ are the vectors of structural and reduced-form parameters, respectively (for detailed variable description see Table 2 ).

\begin{tabular}{ll}
\hline Dependent Variable & \\
\hline \hline Entrepreneurship & $1=$ individual owns enterprise, $0=$ otherwise. \\
\hline \hline Explanatory Variables & $1=$ household borrows microcredit, $0=$ otherwise. \\
\hline Micro credit loan & Age of individual (years). \\
\hline Age & $1=$ individual is male; $0=$ female. \\
\hline Gender & $1=$ individual is married; $0=$ otherwise. \\
\hline Marital status & $1=$ individual has basic and secondary education; $0=$ otherwise. \\
\hline Education category: & $1=$ individual has technical education; $0=$ otherwise. \\
\hline - Technical education & $1=$ individual has tertiary education; $0=$ otherwise. \\
\hline - Tertiary education & The total number of household members. \\
\hline Household size & The ratio of children in household, aged between $0-5$ years. \\
\hline Child ratio & The expenditure of household per capita in logarithm. \\
\hline Expenditure per capita & $1=$ household owns agricultural land, $0=$ otherwise. \\
\hline Land ownership & $1=$ household resides in rural area, $0=$ otherwise. \\
\hline Residence & $1=$ household resides Bishkek or Chui oblast, $0=$ otherwise. \\
\hline Regional dummies for household \\
\hline - Central region & $1=$ household resides Naryn, Talas, Issyk-Kul oblasts, $0=$ otherwise. \\
\hline - North region & $1=$ household resides Jalal-Abad, Osh, Batken oblasts, Osh city, $0=$ otherwise \\
\hline - South region & Share of households with microfinance loan in total household number in \\
\hline \hline
\end{tabular}

Table 2. Variable definitions

However, model estimation in microfinance related researches faces the endogeneity issue; due to correlation of micro-credit loan or participation status with some household's unobserved characteristics, which are not included in model, thus making credits endogenous. In other words, households that are borrowing micro-credit loan may have specific characteristics, which in turn may also have impact on entrepreneurial activities. As it mentioned in Coleman (1999) disregarding the selection bias or endogeneity issue in microcredit program placement may significantly overestimate the impact of program loans. To deal with this problem, we introduce equation (2), an instrumental variable approach, which is the standard method to manage endogeneity. This instrumental variable should obey exclusion restriction, meaning that a variable $x_{2 \mathrm{i}}$ should be related to credit loan $\left(y_{2 \mathrm{i}}\right)$ but not related to entrepreneurship $\left(y_{1 \mathrm{i}}\right)$. Following the literature, in this study the availability of funds at community level will used as the instrumental variable (Bui, 2014; Khandker 2003). For this the share of microcredit borrower households to the total amount of households in the community is calculated. The rationale behind using this type of variable as instrument for microcredit is that community with higher access to microfinance loan would have more households with microfinance loan.

Since our model consists of binary dependent variable and binary endogenous variable (microfinance participation status) the efficient estimation technique for this case is suggested by Roodman (2011) within the 
"conditional mixed process" or CMP. Precisely, it is not appropriate to use standard Instrumental Variable Probit (IV-Probit) command in STATA for discrete endogenous regressors, for this reason the IV-Probit model will be estimated within CMP modelling method.

\section{Estimation results}

Table 3 reports estimation results both in coefficient and marginal effect estimates from IV-Probit CMP. First stage results on using instrumental variable approach within IV-Probit CMP command show that instrumental variable is highly significant. Test of the exogeneity of instrumented variable to outcome variable for models estimated with CMP command is the correlation between the disturbance terms of the first stage and the main equation, which is provided as atanhrho output. The null hypothesis for this is that microcredit participation is uncorrelated with the error term in the occupational choice equation, in our case with entrepreneurship. Due to the rejection of null hypothesis, we can conclude that microcredit participation is endogenous variable, should be corrected for endogeneity in estimation, by using instrumental variable.

\begin{tabular}{|c|c|c|c|}
\hline & \multicolumn{2}{|c|}{ IV-Probit CMP } & \multirow{2}{*}{$\mathrm{dy} / \mathrm{dx}$} \\
\hline & Entrepreneurship & Micro credit loan & \\
\hline Micro credit loan ( $1=$ household borrows credit $)$ & $\begin{array}{c}0.8268 * * * \\
(0.1809) \\
\end{array}$ & & $0.2254 * * *$ \\
\hline \multicolumn{4}{|l|}{ Individual characteristics: } \\
\hline Age & $\begin{array}{c}0.0193 * * * \\
(0.0013)\end{array}$ & $\begin{array}{l}-0.0008 \\
(0.0023)\end{array}$ & $0.0035^{* * *}$ \\
\hline Gender $(1=$ male $)$ & $\begin{array}{c}1.1369 * * * \\
(0.0314) \\
\end{array}$ & $\begin{array}{l}0.1061 * \\
(0.0549)\end{array}$ & $0.1998 * * *$ \\
\hline Marital status $(1=$ married $)$ & $\begin{array}{c}0.1044 * * * \\
(0.0390) \\
\end{array}$ & $\begin{array}{l}-0.1063 \\
(0.0689) \\
\end{array}$ & $0.0184 * * *$ \\
\hline \multicolumn{4}{|c|}{ Educational category (reference: Secondary and basic education) } \\
\hline - $\quad$ Technical education & $\begin{array}{c}-0.6113 * * * \\
(0.0484)\end{array}$ & $\begin{array}{c}-0.2774 * * * \\
(0.0900)\end{array}$ & $-0.0838 * * *$ \\
\hline - $\quad$ Tertiary & $\begin{array}{c}-0.8081 * * * \\
(0.0405)\end{array}$ & $\begin{array}{l}-0.0610 \\
(0.0638) \\
\end{array}$ & $-0.1200 * * *$ \\
\hline \multicolumn{4}{|l|}{ Household characteristics: } \\
\hline Household size & $\begin{array}{c}-0.0256 * * * \\
(0.0098)\end{array}$ & $\begin{array}{c}0.0768 * * * \\
(0.0183) \\
\end{array}$ & $-0.0047 * * *$ \\
\hline Child ratio & $\begin{array}{c}0.2880^{* * *} \\
(0.1016) \\
\end{array}$ & $\begin{array}{l}-0.2786 \\
(0.2019) \\
\end{array}$ & $0.0525 * * *$ \\
\hline Expenditure per capita (log) & $\begin{array}{c}-0.1983 * * * \\
(0.0318)\end{array}$ & $\begin{array}{c}0.4310 * * * \\
(0.0528) \\
\end{array}$ & $-0.0361 * * *$ \\
\hline Land ownership ( $1=$ owns land $)$ & $\begin{array}{c}0.7296^{* * *} \\
(0.0802) \\
\end{array}$ & $\begin{array}{c}0.0717 \\
(0.0946) \\
\end{array}$ & $0.0966^{* * *}$ \\
\hline Residence $(1=$ rural $)$ & $\begin{array}{c}1.0554 * * * \\
(0.0352) \\
\end{array}$ & $\begin{array}{c}0.7369 * * * \\
(0.0727) \\
\end{array}$ & $0.1845^{* * *}$ \\
\hline \multicolumn{4}{|l|}{ Regional dummies (reference: Central region) } \\
\hline - North & $\begin{array}{c}0.7179 * * * \\
(0.0515) \\
\end{array}$ & $\begin{array}{c}0.9428 * * * \\
(0.1754) \\
\end{array}$ & $0.1430 * * *$ \\
\hline - South & $\begin{array}{c}0.5545 * * * \\
(0.0516) \\
\end{array}$ & $\begin{array}{c}0.4130 * * \\
(0.1839) \\
\end{array}$ & $0.1075^{* * *}$ \\
\hline \multicolumn{4}{|l|}{ Instrumental variable: } \\
\hline Microfinance availability & - & $\begin{array}{c}0.0239 * * * \\
(0.0011)\end{array}$ & - \\
\hline Constant & $\begin{array}{c}-2.0255^{* * *} \\
(0.3665)\end{array}$ & $\begin{array}{c}-8.3756 * * * \\
(0.6443)\end{array}$ & - \\
\hline Number of observations & 15897 & & \\
\hline LR chi2 & $7428.04 * * *$ & & \\
\hline Log likelihood & -6921.3912 & & \\
\hline atanhrho_12 & $\begin{array}{c}-0.5819 * * * \\
(0.1350) \\
\end{array}$ & & \\
\hline
\end{tabular}

Table 3. Estimation results (coefficient and marginal effect estimates) 
Findings for our main variable of interest, the dummy variable for microfinance participation show that there is statistically significant and positive relation exists between entrepreneurship and microfinance participation. Meaning that participation in the micro loan rises the probability of individual to be entrepreneur for $22.54 \%$.

The estimated coefficients of explanatory variables have the expected signs and significance levels. Results show that statistically significant gender differences exist among men and women on taking decision to be entrepreneur. Thus men are more likely to be entrepreneur with respect to women for $19.98 \%$. While with increase of age, the probability of being entrepreneurs is increasing little. In other words, entrepreneurial status of individual is positively related to its age, which may indicate that individual with age getting more experienced in labor market and makes decision on owning own enterprise. The same can be concluded for marital status of individual, though the probability is not high but married individual more likely to be entrepreneurs rather than unmarried ones.

More educated individual are less likely to be entrepreneurs. This could be explained with labor market specification in Kyrgyzstan, own-account workers or entrepreneurs mostly maintain, manage small trade markets, shops, which do not require particular educational or labor skills. Along with these characteristics in Kyrgyzstan, most of the individuals with land ownership are considered as own-account workers. It means that even if individuals are not employed at any other sectors, but just work as family unpaid agriculture worker with low productivity they are considered as own-account worker. The dummy variable showing ownership of land by household has positive and significant effect on entrepreneurship decision of individual. Showing that individuals in households with agricultural land, more likely to be entrepreneur than those, who are in households without agricultural land.

Residence of household has impact on entrepreneur decision of individual. Thus individuals residing in rural household for $18.45 \%$ are more likely to be entrepreneur than those residing in urban areas. Moreover, regional differences in entrepreneurship can be observed. The estimation results show that individuals from north and south regions are more likely to be entrepreneur with respect to those, who are residing in Bishkek city or Chui oblast for $14.30 \%$ and $10.75 \%$ respectively. Showing that individuals from central region more likely to be wage paid workers.

\section{Conclusion}

Using the Kyrgyz Integrated Household Survey data for 2013 the present study analyzed the impact of microfinance impact on entrepreneurship. For this binary dependent IV-Probit model is estimated. The entrepreneurship is observed in case if individual owns an enterprise. The probability of individual to be an entrepreneur is conditional on explanatory variables, such as micro-credit participation and other individual and household characteristics. Estimation results show that participation in the micro loan rises the probability of individual to be entrepreneur, showing that in general wide spread micro-credit loan in Kyrgyzstan has positive effect on entrepreneurial activity. Results on the individual and household level characteristics show that the decision of being entrepreneur is highly dependent not only individual characteristics, but also on households" characteristics, such as location, composition and wealth of households.

There is a significant gender difference among men and women on taking decision to be entrepreneur, thus men are more likely to be entrepreneur with respect to women. One of the interesting findings is that elderly, less educated and married individuals are more likely to be entrepreneur. This findings show that in Kyrgyzstan entrepreneurship mostly presented by unskilled workers, which may be conditional on the fact that owning enterprise in Kyrgyzstan, in most times presented in managing small trade markets, shops, owning land to generate income which do not require particular educational or labor skills.

Therefore, we can conclude that entrepreneurship in Kyrgyzstan mostly presented by micro-enterprises located mostly in rural areas, and that micro-credit currently plays role as one of important instrument in facilitating financial access in non-urban areas, where the financial institutions are not wide-spread.

\section{References}

- Angioloni, S., Kudabaev, Z., Ames, G. C., \&Wetzstein, M. E. (2013). Micro-credit impact in Kyrgyzstan: A study case. Southern Agricultural Economics Association, 23.

- Babajide, A. (2012). "Effects of Microfinance on Micro and Small Enterprises (MSEs) Growth in Nigeria" Asian Economic and Financial Review Vol.2, No. 3, pp. 463-477.

- Buera, F. J., Kaboski, J. P., \& Shin, Y. (2012). The macroeconomics of microfinance (No. w17905). National Bureau of Economic Research.

- Bui, L. T. V. (2014). Microfinance and Poverty Alleviation: Does Credit Access Contribute to Reduce Household Poverty in Vietnam?.

- Chowdhury, M. J. A., Amin, S., \&Farha, T. (2012). Access to Credit and Women Entrepreneurship: Evidence from Bangladesh. 
- Coleman, B. E. (1999). The impact of group lending in Northeast Thailand. Journal of Development Economics, 60(1), 105-141.

- $\quad$ Field, E., Pande, R., Papp, J., \&Rigol, N. (2013). Does the classic microfinance model discourage entrepreneurship among the poor? Experimental evidence from India. The American Economic Review, 103(6), 2196-2226.

- Karlan, D., \& Valdivia, M. (2011). Teaching entrepreneurship: Impact of business training on microfinance clients and institutions. Review of Economics and Statistics, 93(2), 510-527.

- $\quad$ Khandker, S. R. (2003). Micro-finance and poverty: evidence using panel data from Bangladesh. World Bank Policy Research Working Paper, (2945).

- $\quad$ Khandker, S. R. (2005). Microfinance and poverty: Evidence using panel data from Bangladesh. The World Bank Economic Review, 19(2), 263-286.

- Kholis, N., (2009). "The Contribution of Islamic Microfinance Institution in Increasing Social Welfare in Indonesia (A Case Study of Bmt's Role at Pakem Market Micro Traders Yogyakarta)”. In International Seminar on Islamic Financial Engineering. (2009):1-25

- Newey, W. K. (1987). Efficient estimation of limited dependent variable models with endogenous explanatory variables. Journal of Econometrics 36: 231-250.

- $\quad$ NSCKR, National Statistics Committee Of Kyrgyz Republic, http://stat.kg/index.php?option=com_content\&task=view\&id=37\&Itemid=101, accessed in May 2015

- $\quad$ Pitt, M. M., \&Khandker, S. R. (1998). The impact of group-based credit on poor households in Bangladesh: Does the gender of participants matter? Journal of Political Economy, 106, 958-996.

- Roodman, D. (2009). Estimating fully observed recursive mixed-process models with cmp. Available at SSRN 1392466.

- Roodman, D., \&Morduch, J. (2014). The impact of microcredit on the poor in Bangladesh: Revisiting the evidence. Journal of Development Studies, 50(4), 583-604.

- Sultakeev, Kadyrbek. (2012) “Kırgızistan'daYoksulluğuÖnlemedeMikrokrediUygulamaları” (Microcredit practice and poverty alleviation in Kyrgyzstan), Master Thesis, Kyrgyz-Turkish Manas University, 2012.

- The Kyrgyz Republic Law “About restriction of usurious activities in the Kyrgyz Republic”, Public Law 163, 24 July, 2013

- The Kyrgyz Republic Law “On Micro-finance organizations in the Kyrgyz Republic”, Public Law 124, (23 July, 2002) 3.

- Valdivia, M. (2011). Teaching entrepreneurship: Impact of business training on microfinance clients and institutions. Review of Economics and Statistics, 93(2), 510-527.

- Wang, X. (2013). The Impact of Microfinance on the Development of Small and Medium Enterprises: The Case of Taizhou, China. 